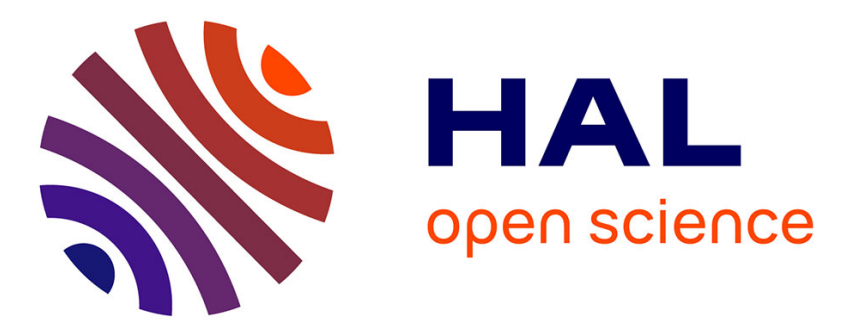

\title{
ABCB1 (P-glycoprotein) regulates vitamin D absorption and contributes to its transintestinal efflux
}

Marielle Margier, Xavier Collet, Cédric Le May, Charles Desmarchelier, François André, Chantal Lebrun, Catherine Defoort, Alice Bluteau, Patrick

Borel, Anne Lespine, et al.

\section{To cite this version:}

Marielle Margier, Xavier Collet, Cédric Le May, Charles Desmarchelier, François André, et al.. ABCB1 (P-glycoprotein) regulates vitamin D absorption and contributes to its transintestinal efflux. FASEB Journal, 2019, 33 (2), pp.2084-2094. 10.1096/fj.201800956R . hal-01986017

\section{HAL Id: hal-01986017 https://hal-amu.archives-ouvertes.fr/hal-01986017}

Submitted on 18 Feb 2019

HAL is a multi-disciplinary open access archive for the deposit and dissemination of scientific research documents, whether they are published or not. The documents may come from teaching and research institutions in France or abroad, or from public or private research centers.
L'archive ouverte pluridisciplinaire HAL, est destinée au dépôt et à la diffusion de documents scientifiques de niveau recherche, publiés ou non, émanant des établissements d'enseignement et de recherche français ou étrangers, des laboratoires publics ou privés. 
ABCB1 (P-glycoprotein) regulates vitamin D absorption and contributes to its transintestinal efflux

Marielle Margier ${ }^{1}$, Xavier Collet ${ }^{2 *}$, Cédric le May $^{3 *}$, Charles Desmarchelier $^{1}$, François André ${ }^{4}$, Chantal Lebrun $^{6}$, Catherine Defoort ${ }^{1,5}$, Alice Bluteau ${ }^{6}$, Patrick Borel ${ }^{1}$, Anne Lespine**6, Emmanuelle Reboul $* * * 1$

${ }^{1}$ C2VN, INRA, INSERM, Aix-Marseille Univ, Marseille, France.

${ }^{2}$ INSERM, UMR1048, Institute of Metabolic and Cardiovascular Diseases, University of Toulouse, Toulouse, France

${ }^{3}$ Institut du thorax, INSERM, CNRS, UNIV Nantes, Nantes, France

${ }^{4}$ I2BC, CNRS UMR 9198, CEA/Institut de Biologie Frédéric Joliot, Université Paris-Saclay; 91191 Gifsur-Yvette cedex, France

${ }^{5}$ CRIBIOM, Criblage Biologique Marseille, Faculté de Médecine de la Timone, Marseille, France.

${ }^{6}$ INTHERES, Université de Toulouse, INRA, ENVT, Toulouse, France

* These authors contributed equally to the manuscript.

\section{For correspondence:}

** Dr Anne Lespine, INRA-InTheRes_UMR 1436, 180, Chemin de Tournefeuille, BP 93173, F-31027

Toulouse Cedex 3; +33(0)582066352; anne.lespine@inra.fr.

*** Dr Emmanuelle Reboul, Centre for Cardiovascular and Nutrition Research (C2VN), Faculty of

Medicine, 27 Bd Jean Moulin, 13385 Marseille cedex 5; France. +33(0)491324278;

Emmanuelle.Reboul@univ-amu.fr.

Short running title: $\mathrm{ABCB} 1$ and vitamin $\mathrm{D}$ intestinal transport

Sources of support: Marielle Margier received a doctoral fellowship (2015-2018) from Region PACA (France) in partnership with the Centre Technique de Conservation des Produits Alimentaires (CTCPA Avignon, France). This work was partly supported by a Research Price from the French Nutrition Society (SFN). 


\section{Abbreviations}

ABCB1, ATP Binding Cassette Subfamily B Member 1; Abcb1-/- mice, mice deficient for the two murine ABCB1s encoded by Abcbla and Abcb1b genes; BSA, Bovine serum albumin; Cel-Pgp-1, Coenorhabditis elegans P-glycoprotein 1; CD36, CD36 molecule; $\mathrm{D}_{3}$, cholecalciferol; 1,25(OH) $)_{2} \mathrm{D}_{3}, 1,25$ -

dihydroxycholecalciferol; DMEM, Dulbecco's Modified Eagle's medium; HBSS, Hanks' Balanced Salt Solution; 25(OH)D 3 , 25-hydroxycholecalciferol; MDCK, Madin-Darby canine kidney type II cells; NBD, nucleotide binding domain; NPC1L1, NPC1 like Transporter ; SNPs, single-nucleotide polymorphisms; SRBI Scavenger Receptor Class B type I, TM(D), transmembrane (domain). 


\begin{abstract}
Efficient intestinal absorption of dietary vitamin D is required in most people to ensure an adequate status. We thus investigated the involvement of ATP-binding cassette B1 (ABCB1) in vitamin D intestinal efflux. Both cholecalciferol and 25-hydroxycholecalciferol apical effluxes were decreased by chemical inhibition of ABCB1 in Caco-2 cells and increased by $A B C B 1$ overexpression in Griptites or MDCKII cells. $A b c b 1^{-/-}$ mice displayed an accumulation of 25-hydroxycholecalciferol in plasma, intestine, brain, liver and kidneys, together with an increased cholecalciferol postprandial response after gavage, compared with controls. Twenty-five-hydroxycholecalciferol efflux through $A b c b 1^{-/}$intestinal explants was markedly decreased compared with controls. This reduction of 25-hydroxycholecalciferol transfer from plasma to lumen was further confirmed in vivo in intestine-perfused mice. Docking experiments established that both cholecalciferol and 25-hydroxycholecalciferol could bind with high affinity to Caenorhabditis elegans pglycoprotein used as an ABCB1 model. Finally, in a group of 39 healthy male adults, a SNP in $A B C B 1$ (rs17064) was significantly associated with the fasting plasma 25-hydroxycholecalciferol concentration. We thus showed here for the first time that ABCB1 is involved in neo-absorbed vitamin D efflux by the enterocytes, and that it also contributes to vitamin D transintestinal excretion and likely impacts on vitamin D status.
\end{abstract}

Keywords: Cholecalciferol; 25-hydroxycholecalciferol; bioavailability, enterocyte, MDR1 


\section{Introduction}

Vitamin D is essential for health and is involved in many functions including the optimal functioning of the musculoskeletal system. Indeed, it stimulates both dietary calcium absorption and osteoid mineralization, and has major regulating roles in bone turnover and muscle function (1). Consequently, hypovitaminosis D is associated with defects in bone development in infants as well as with osteoporosis in postmenopausal women, and it can severely impact welfare and health in elderly populations in general. As vitamin D deficiency and insufficiency are extremely prevalent in the general population worldwide, this represents today a major public health concern (2).

Vitamin D is a generic term that includes several cholesterol-derived compounds such as vitamin $D_{3}\left(D_{3}\right.$, cholecalciferol), and its metabolites 25-hydroxycholecalciferol $\left(25(\mathrm{OH}) \mathrm{D}_{3}\right)$ and 1,25-

dihydroxycholecalciferol $\left(1,25(\mathrm{OH})_{2} \mathrm{D}_{3}\right)$. $\mathrm{D}_{3}$ can be either synthetized in the skin from 7-dehydrocholesterol under the influence of UV light, or provided through the diet. After synthesis/absorption, $\mathrm{D}_{3}$ is taken up by the liver where it is metabolized into $25(\mathrm{OH}) \mathrm{D}_{3}$ and released to the blood stream associated with its specific binding protein. Vitamin D insufficiency and deficiency are defined as low $25(\mathrm{OH}) \mathrm{D}_{3}$ circulating levels $(2)$. The vitamin D active hormonal form 1,25-dihydroxycholecalciferol is finally synthetized from $25(\mathrm{OH}) \mathrm{D}_{3}$ in the kidneys or locally in target tissues (3). Since sun exposure cannot provide sufficient vitamin D in most people, supply through dietary intake is usually required. Therefore, intestinal absorption of the dietary vitamin D is an essential process for maintaining optimal vitamin D status.

Vitamin D intestinal absorption has long been thought to occur through passive diffusion (4), but we have recently shown that membrane transporters of cholesterol such as Scavenger Receptor Class B type I (SRBI), CD36 molecule (CD36) and to a lesser extend NPC1 like Transporter 1 (NPC1L1), facilitate $\mathrm{D}_{3}$ intestinal absorption (5), but not that of $25(\mathrm{OH}) \mathrm{D}_{3}(6)$. In addition, the efflux of neo-absorbed $\mathrm{D}_{3}(5)$ and $25(\mathrm{OH}) \mathrm{D}_{3}(6)$ from Caco-2 cells into the apical medium in the presence of mixed micelles strongly suggests the existence of an active excretion of the vitamin D from the intestine into the lumen. Such luminal efflux is a key limiting process of the absorption of a large number and variety of lipids and xenobiotics, and its complete mechanisms is poorly understood. Several export pumps are likely to be involved in this phenomenon, among which multidrug resistance proteins of the ABCB subfamilies, such as $\mathrm{ABCB}$, also known as P-glycoprotein (Pgp) (7).

$\mathrm{ABCB} 1$ is a $170 \mathrm{kDa}$ transmembrane protein from the ATP-powered pump family, made of two ATPbinding domains and transmembrane hydrophobic domains that delineate a large multispecific binding pocket with a wide drug recognition capacity. This protein can thus actively efflux a broad range of structurally unrelated hydrophobic compounds, and plays a central role in protecting tissues from accumulation of xenobiotics and their endogenous metabolites (7). It also affects the uptake and distribution 
of several endogenous lipids from the intestine, such as steroid hormones (8). In particular, ABCB1 participates in cholesterol transintestinal excretion (TICE), contributing to cholesterol homeostasis (9). Since cholesterol and vitamin D are structurally related and share common uptake routes (5), we hypothesized that they could also share common efflux pathways. We thus investigated whether ABCB1 could export this vitamin at the intestinal level by conducting cellular, animal, in silico and human experiments. 


\section{Material and methods}

\section{In vitro studies}

Caco-2 cells. Caco-2 clone TC-7 cells were cultured, seeded and grown on transwells as previously described $(10,11)$. Twelve hours prior to each experiment, cells received micellar vitamin $\mathrm{D}$ at the apical side $(10 \mu \mathrm{M})$ and complete medium (DMEM - Dulbecco's Modified Eagle's medium - supplemented with $10 \%$ fetal bovine serum, $1 \%$ nonessential aminoacids and 1\% penicillin/streptomycin) at the basolateral side. Cells were rinsed once with PBS and once with mixed micelles without vitamin D. Cells then received mixed micelles without vitamin D supplemented or not with either valspodar 0.1-5 $\mu \mathrm{M}$ (PSC 833, MedChemExpress), Zosuquidar $1 \mu \mathrm{M}$ (Sigma Aldrich) or KO143 $1 \mu \mathrm{M}$ (Sigma Aldrich) at the apical side, and complete media at the basolateral side for $4 \mathrm{~h}$. The media were harvested, cells were rinsed with PBS and scraped into $0.5 \mathrm{ml}$ ice-cold PBS.

Griptite cells. Griptite 293MSR cells were cultured and transfected with either $A B C B 1$-pCMV plasmid or empty pCMV plasmid as previously described $(12,13)$. Transfection efficiency was verified by western blotting (14). Cells then received complete medium enriched with $10 \mu \mathrm{M}$ vitamin $\mathrm{D}$ in ethanol (final ethanol concentration $<0.1 \%$ ) for $12 \mathrm{~h}$. Cells were then rinsed twice with DMEM and received mixed micelles diluted in DMEM (1:4; vol:vol) as efflux medium. After $2 \mathrm{~h}$ incubation, $1 \mathrm{ml}$ of medium was harvested and replaced by the same volume of efflux medium. After $4 \mathrm{~h}$, the media were harvested, cells were rinsed with PBS and scraped into $0.5 \mathrm{ml}$ ice-cold PBS.

MDCK cells. MDCK-II (Madin-Darby canine kidney strain II) epithelial cells and MDCK-II cells transfected with human $A B C B 1$ gene (MDCKII- $A B C B 1$ ) were provided by The Netherland Cancer Institute (Amsterdam). Cells (passage 10 to 16) were cultured similarly to Griptite cells. For experiment, cells were seeded at a density of $5.0 \times 10^{6}$ cells/well on polycarbonate membrane inserts (6-well plate, $1 \mu \mathrm{m}$-pore-size Polyethylene Terephthalate membrane; Merck Millipore). Four to 5 days after seeding cells reached monolayers and they were washed in PBS. The basolateral side of the cell monolayers received HBSS (Hanks' Balanced Salt Solution) supplemented with 1\% BSA and containing $10 \mu \mathrm{M} \mathrm{D}_{3}$ or $25(\mathrm{OH}) \mathrm{D}_{3}$, whereas the apical side received HBSS supplemented with 1\% BSA (efflux medium). At $2 \mathrm{~h}, 0.5 \mathrm{ml}$ of the apical medium were harvested and replaced by the same volume of new efflux media. At $4 \mathrm{~h}$, both apical and basolateral media were harvested. Cells were rinsed and scraped into $0.5 \mathrm{ml}$ ice-cold PBS.

HsABCB1 ATPase activity measurements. ATPase activity was measured in membranes of Sf9 insect cells infected with a recombinant baculovirus containing the human $A B C B 1$ cDNA (Tebu-Bio), without or with $5 \mu \mathrm{M}$ of verapamil, in absence or in the presence of $40 \mu \mathrm{M}$ of either $\mathrm{D}_{3}$ or $25(\mathrm{OH}) \mathrm{D}_{3}$, and using a modification of the endpoint inorganic phosphate (Pi) release assay described by Sarkadi et al. (15). A duplicate reaction mixture also containing an ABCB1 ATPase inhibitor, i.e. sodium orthovanadate 100 $\mu \mathrm{M}$, was assayed in parallel as a negative control. The amount of Pi released was determined at each time 
point in triplicate, and the mean initial hydrolysis rate was calculated in $\mathrm{nmol} \mathrm{Pi} / \mathrm{min} / \mathrm{mg}$ of total membrane protein.

\section{Mouse experiments}

Ethics. Animals and standard operating procedures were conducted under European laws on the protection of animals (86/609/EEC) and adhered to the guidelines from the institutional animal care committee for good clinical practice (CVMP/VICH 59598). The protocols for vitamin D gavage and postprandial measurement of plasma vitamin D response in mice were approved by the local institutional animal care and ethics committee of the "Direction Départementale des Services Vétérinaires de HauteGaronne" (specific approval number B31555-25). Transintestinal excretion measurement in mice were approved by the Ethic Committee for Animal Experimentation of Pays de la Loire (specific approval number 01953.01).

Animals. FVB control mice $\left(A b c b 1^{+/+}\right)$and FVB deficient mice for the two murine ABCB1s encoded by $A b c b 1 a$ and $A b c b 1 b$ genes (GenBankTM Accession numbers NM011076 and NM011075, respectively) ( $A b c b 1^{-/}$mice), were obtained from Taconic (Germantown, NY, USA) and kept as previously described (16). Experiments were carried out on 8-15-week-old mice (20-30 g).

Tissue collection. Animals ( $\mathrm{n}=3$ to 9 ) were euthanized at fast by cervical dislocation. Brain, kidney and liver samples were then taken and snap-frozen into liquid nitrogen.

Postprandial experiment with $\boldsymbol{D}_{3}$. Postprandial experiment was conducted on male mice ( $\mathrm{n}=4$ to 5 in each group) as previously described (13). Plasma samples were taken at fast. Gavage emulsions were prepared as previously described (5) to provide $250 \mu \mathrm{g}$ of $\mathrm{D}_{3}$ to each mouse.

Measure of transintestinal vitamin D efflux in Ussing chambers. Median jejunum was removed from $\mathrm{Abcbl}^{+/+}(\mathrm{n}=3)$ and $A b c b 1^{-/}$mice $(\mathrm{n}=3)$, mounted on sliders and fixed into Ussing chambers (Physiological Instruments, San Diego, CA). Both chambers contained $1 \mathrm{~mL}$ of oxygenated $\left(95 \% \mathrm{O}_{2} / 5 \%\right.$ $\mathrm{CO}_{2}$ ) Krebs-Henseleit medium (Sigma) supplemented with $1 \%$ of BSA, and maintained at $37^{\circ} \mathrm{C}$. At the start of the experiment, vitamin D $10 \mu \mathrm{M}$ was added in the basolateral chamber, while the apical chamber contained vitamin D-free mixed micelles. Apical medium $(250 \mu \mathrm{L})$ was collected at $15 \mathrm{~min}$ and replaced by fresh medium for additional $15 \mathrm{~min}$ incubation.

Transintestinal Efflux in vivo measurement. Perfusion procedures was performed on male mice ( $\mathrm{n}=7$ for $\mathrm{Abcbl}^{+/+}$and $\mathrm{n}=9$ for $A b c b 1^{-/}$mice) as previously described (9) after intravenous injection of $\mathrm{H}^{3}$ $25(\mathrm{OH}) \mathrm{D}_{3}$ dissolved in intralipid ${ }^{\circledR}\left(0.25 \mu \mathrm{Ci}\right.$ of $\mathrm{H}^{3}-25(\mathrm{OH}) \mathrm{D}_{3}$ in $\left.100 \mu \mathrm{l}\right)$. Intestinal perfusates $(500 \mu \mathrm{l})$ were mixed with $5 \mathrm{ml}$ of liquid scintillation (ECOLITE, Perkin Elmer) and radiolabeled vitamin levels were assessed by liquid scintillation counting. 


\section{Lipid analysis}

Total lipids in mouse plasma samples were analyzed as previously described (17).

\section{Vitamin D extraction, HPLC and LC-MS ${ }^{2}$ analysis.}

All the samples from experiments were stored at $-80^{\circ} \mathrm{C}$ under nitrogen before vitamin $\mathrm{D}$ analysis. All solvents used were from Carlo-Erba.

Cell samples and mouse postprandial experiment samples. The internal standards were ergocalciferol and retinyl acetate for samples containing $25(\mathrm{OH}) \mathrm{D}_{3}$ and $\mathrm{D}_{3}$, respectively. Samples were extracted and analyzed in a Shimadzu HPLC system as previously described $(5,10)$. The dried extracts were dissolved in $80 \mu 1$ acetonitrile and a volume of $50 \mu 1$ was used for HPLC analysis. $\mathrm{D}_{3}$ and retinyl acetate, as well as $25(\mathrm{OH}) \mathrm{D}_{3}$ and ergocalciferol, were separated using a $100 \times 4.6 \mathrm{~mm}$ Kinetex $5 \mu \mathrm{m} \mathrm{C18} 100 \AA$ column (Phenomenex) with a C18 guard column (Phenomenex). The mobile phase involved a gradient of acetonitrile (A) and water (B). Flow rate was $1.2 \mathrm{ml} / \mathrm{min}$. The gradient profile of the mobile phase (A:B) was set at 70:30 for $6.5 \mathrm{~min}$ and changed linearly to $90: 10$ in $8.5 \mathrm{~min}$, and then the mobile phase was changed back to $70: 30$ from 18.5 to $21 \mathrm{~min}$. The column was kept at a constant temperature $\left(40^{\circ} \mathrm{C}\right) . \mathrm{D}_{3}$ and $25(\mathrm{OH}) \mathrm{D}_{3}$ quantification was performed using Chromeleon software (version 6.50 SP4 Build 1000, Dionex) comparing peak area with standard reference curves.

Mouse plasma and tissue samples. Samples were extracted and analyzed by LC-MS². Isotopically labelled d3- $\mathrm{D}_{3}, \mathrm{~d} 3-25(\mathrm{OH}) \mathrm{D}_{3}$ and $\mathrm{d} 3-1,25$ (Cambridge Isotope Laboratories) were used as internal standards. Plasma samples were prepared as previously described (18) and derivatized with Ampliflex Diene (Sciex) reagent (19). Tissue samples were prepared as previously described (20) and derivatized with either Ampliflex (19) or 4-phenyl-1,2,4-triazoline-3,5-dione (PTAD, Sigma) reagents (20). Accurate mass measurements were performed on the Q- Exactive Plus mass spectrometer (Thermo Fisher Scientific) equipped with a Heated Electrospray Ionization (H-ESI II) probe. Thermo Xcalibur 3.0.63 software was used for both instrument setup and control, and for data treatment. Tune Q Exactive Plus 2.5 software was used for direct control of the mass spectrometer. The autosampler tray was kept at $4{ }^{\circ} \mathrm{C}$ and the column was kept $40{ }^{\circ} \mathrm{C}$. Five $\mu \mathrm{L}$ of sample were injected onto a Hypersil GOLD C18 column $(2.1 \times 100 \mathrm{~mm}$; Thermo Fisher Scientific). The solvents were : (A) water - formic acid $0.1 \%$ and (B) was $0.1 \%$ acetonitrile - formic acid $0.1 \%$. Solvent flow rate was set at $400 \mu \mathrm{L} / \mathrm{min}$. For Amplifex assays, the proportions of solvent B used were: 0-4 $\min : 30 \%$, 4-10 $\min : 30-65 \%$, 10-12 $\min : 65 \%$, 12-16 $\min :$ 65-100\%, 16-18 $\min : 100 \%-30 \%$. For PTAD assays, the proportions of solvent B used were: 0-1 $\mathrm{min}: 50 \%, 1-13 \mathrm{~min}: 50-100 \%, 13-15 \mathrm{~min}$ : 100\%, 15-16 $\mathrm{min}:$ 100-50\%, 16-18 $\mathrm{min}: 50 \%$. LC-HRMS/MS analyses were performed in positive ionization mode. The H-ESI probe and the transfer capillary temperature were kept at $310^{\circ} \mathrm{C}$ and $320^{\circ} \mathrm{C}$, respectively. Spray voltage was set at $3500 \mathrm{~V}$ and the S-lens radiofrequency level at $55 \mathrm{~V}$. Sheath and 
auxiliary gas were maintained at 30 and 8 (arbitrary units). Parallel Reaction Monitoring method was set up as MS/MS acquisition mode and full higher-energy collision dissociation spectra (HCD) spectra were acquired. For each compound, the most abundant ion was selected as precursor ion and isolated in a 2 Uma window in a specified time segment and fragmented under optimized collision energies. The resolving power was set to 35000 full width at half maximum at m/z 200 .

\section{Sample preparation and Real-time PCR.}

Total RNA was extracted from the duodenal mucosa of mice ( $n=4$ per group) using TRIzol reagent (Euromedex, France). Total RNA concentration and quality were confirmed with the use of the biodrop $\mu$ Lite (Sciences tec). cDNAs were synthesized from $1 \mu \mathrm{g}$ total RNA. Real time quantitative PCR assays were performed with Sybr green mixes using a thermocycler Light Cycler 480 (Roche). For each condition, expression was quantified in duplicate, and $18 \mathrm{~s}$ rRNA was used as endogenous control in the comparative cycle threshold (CT) method. Primer sequences were $18 \mathrm{~s}$ [F: CGCCGCTAGAGGTGAAATTCT and R: CATTCTTGGCAAATGCTTTCG], $v d r$ [F: CTGTACCCCAGGTCGGTCT and R: AACCCCTCATAAAGTTCCAGGT].

\section{Vitamin D docking on ABCB1}

The ABCB1 of the nematode C. elegans p-glycoprotein 1 (Cel-Pgp-1) X-ray structure, determined at a resolution of $3.4 \AA$ (PDB code 4F4C) (21), was used in all docking calculations. Preparation of protein target structure and of ligands conformations, docking procedure, data analysis and identification of key residues are detailed in (22). The molecular structures of ligands were extracted from Chemspider (CID 4444353 and 4446820 for $\mathrm{D}_{3}$ and $25(\mathrm{OH}) \mathrm{D}_{3}$, respectively), and ten conformers generated by MarvinSketch in order to select several lowest energy ring conformers as starting point for flexible docking calculations. Molecular docking experiments were performed using AutoDock 4 (release 4.2.6), with 100 poses in each docking run. The most representative poses of the docking experiments were chosen for data presentation, according to the score calculated by AutoDock, which can be considered as an estimated free energy of ligand binding, thus indicative of binding affinity. Other parameters and observables were used in the interpretation of docking data issued by AutoDock: histogram bars energy range, profile of the histogram, and location of calculated positions in the protein structure. For each lowest energy pose of selected clusters, the number and nature of interacting residues were analyzed within the protein. Among these, particular interest was given to residues belonging to the "hotspots" for drug binding (22).

Association between single-nucleotide polymorphisms (SNPs) in ABCB1 and fasting plasma 25(OH) $D_{3}$ concentrations in healthy male adults 
Thirty-nine healthy male adults were recruited for the study (NCT02100774, ClinicalTrials.gov) and their fasting plasma $25(\mathrm{OH}) \mathrm{D}_{3}$ concentration was measured as previously described (23). They were genotyped using whole-genome microarrays (24). One hundred and fourteen SNPs in $A B C B 1$ were expressed on the arrays. SNPs for which the genotype call rate was $<95 \%$, or SNPs that presented a significant departure from the Hardy-Weinberg equilibrium ( $p<0.05$; Chi-squared test), were excluded from all subsequent analyses. TagSNPs were selected using the LD TAG SNP Selection (TagSNP) tool from the SNPinfo Webserver (https://snpinfo.niehs.nih.gov/snpinfo/snptag.html) using genotype data from HapMap in the CEU population and with a linkage disequilibrium cut-off of 0.8 . This resulted in the selection of 36 candidate tag SNPs. A dominant genetic model was assumed: for each SNP, subjects homozygous for the lesser frequent allele were grouped with heterozygous subjects. SNPs for which they were fewer than 5 subjects in a genotypic group were excluded from further statistical analysis.

\section{Statistical analysis}

Results are expressed as means \pm SEM. Differences between more than two groups of unpaired data were analyzed using the nonparametric Kruskal-Wallis test while differences between two groups of unpaired data were tested by the Mann-Whitney U test, using Statview software, version 5.0 (SAS Institute, Cary, NC).

The associations between the 21 selected SNPs in $A B C B 1$ and the $25(\mathrm{OH}) \mathrm{D}_{3}$ concentration were analyzed by Student's t-test with the Benjamini-Hochberg correction for multiple testing, using QVALUE (version 1.0, designed by researcher) (25) and $\mathrm{R}$ softwares (version 3.0.2, R foundation of statistical computing).

For all tests, an adjusted $\mathrm{p}$-value $<0.05$ was considered significant. 


\section{Results}

\section{ABCB1 is involved in vitamin $D$ apical efflux in vitro in cells}

We first measured vitamin D efflux in several epithelial cell models expressing different levels of ABCB1. In Caco-2 TC7 cells, the ABCB1 inhibitor PSC833 (valspodar $1 \mu \mathrm{M}$ or $5 \mu \mathrm{M}$ ) induced a significant decrease of the apical efflux of both $\mathrm{D}_{3}$ and $25(\mathrm{OH}) \mathrm{D}_{3}$ (up to $-28.1 \%$ and $-21.8 \%$, Figure $1 \mathrm{~A}$ ). Valspodar $0.1 \mu \mathrm{M}$ also significantly decreased $\mathrm{D}_{3}$ efflux by $18.5 \%$. Zosuquidar $1 \mu \mathrm{M}$ significantly reduced of both $\mathrm{D}_{3}$ and $25(\mathrm{OH}) \mathrm{D}_{3}$ efflux (-27.7\% and $-34.9 \%$, Figure 1B). Conversely, KO143 $1 \mu \mathrm{M}$ reduced $\mathrm{D}_{3}(-30.4 \%)$ but not $25(\mathrm{OH}) \mathrm{D}_{3}$ efflux (Figure 1C). The transitory transfection with $A B C B 1$ of Griptite cells significantly increased the $\mathrm{D}_{3}$ apical efflux, when compared with cells transfected with an empty plasmid $(+32.2 \%$ at $2 \mathrm{~h}$, $+34.8 \%$ at $4 \mathrm{~h} ; \mathrm{p}<0.05$; Figure $1 \mathrm{D})$. This transitory transfection also significantly increased the $25(\mathrm{OH}) \mathrm{D}_{3}$ apical efflux when compared with cells transfected with an empty plasmid $(+21.2 \%$ at $2 \mathrm{~h},+25.0 \%$ at $4 \mathrm{~h}$; $\mathrm{p}<0.05$; Figure 1D). Finally, when ABCB1 was overexpressed in stable $A B C B 1$ gene-transfected MDCK-II cells, the trans-epithelial effluxes of both $\mathrm{D}_{3}$ and $25(\mathrm{OH}) \mathrm{D}_{3}$ were significantly increased compared with the parental MDCK-II $\left(+167.1 \%\right.$ at $2 \mathrm{~h},+125.7 \%$ at $4 \mathrm{~h}$ for $\mathrm{D}_{3}$ and $+139.0 \%$ at $2 \mathrm{~h},+54.1 \%$ at $4 \mathrm{~h}$ for $\left.25(\mathrm{OH}) \mathrm{D}_{3} ; \mathrm{p}<0.05\right)$ (Figures 1E).

\section{Vitamin D modulates ABCB1 ATPase activity}

It is generally admitted that the ATPase activity of ABCB1 can be modulated by its own substrates. Therefore, we measured this activity on inversed vesicles prepared from cells that overexpressed $\mathrm{HsABCB} 1$, in presence of $\mathrm{D}_{3}$ or $25(\mathrm{OH}) \mathrm{D}_{3}$ (Figure $1 \mathrm{~F}$ ). In our experimental conditions, $\mathrm{D}_{3}$ at $40 \mu \mathrm{M}$ activated moderately the ATPase activity while $25(\mathrm{OH}) \mathrm{D}_{3}$ had no effect on the basal ABCB1-ATPase activity. Nevertheless, both compounds inhibited ABCB1-verapamil-stimulated ATPase, which confirms that $\mathrm{D}_{3}$ and $25(\mathrm{OH}) \mathrm{D}_{3}$ interacted directly with $\mathrm{ABCB} 1$.

\section{ABCB1 deficiency in mice is associated with higher vitamin D status}

In order to confirm our in vitro results, we assessed the impact of $\mathrm{ABCB} 1$ on vitamin $\mathrm{D}$ homeostasis in mice. The plasma concentrations of both $\mathrm{D}_{3}$ and $25(\mathrm{OH}) \mathrm{D}_{3}$ were respectively $58.8 \%$ and $42.6 \%$ higher in $A b c b 1^{-/}$mice compared with $A b c b 1^{+/+}$mice ( $\mathrm{p}<0.01$ and $\mathrm{p}<0.001$, respectively), while plasma $1,25(\mathrm{OH})_{2} \mathrm{D}_{3}$ remained unchanged (Figure 2A).

Vitamin D concentrations were significantly higher in both fasting intestine $\left(+115.4 \%\right.$; $<<0.05$ for $\mathrm{D}_{3}$ and $+43.0 \% ; \mathrm{p}<0.05$ for $25(\mathrm{OH}) \mathrm{D}_{3}$, respectively, Figure $\left.2 \mathrm{~B}\right)$ and brain of $A b c b 1^{-/}$mice $(+65.6 \% ; \mathrm{p}<0.005$ for $\mathrm{D}_{3}$ and $+58.2 \% ; \mathrm{p}<0.05$ for $25(\mathrm{OH}) \mathrm{D}_{3}$, respectively, Figure $\left.2 \mathrm{C}\right)$. In addition, in $A b c b 1^{-/}$mice, $25(\mathrm{OH}) \mathrm{D}_{3}$ concentration was significantly higher in kidney $(+20.6 \%$; $<0.02$, Figure $2 \mathrm{D})$ and liver $(+59.2 \% ; \mathrm{p}<0.02$, 
Figure $2 \mathrm{C}$ ), while $\mathrm{D}_{3}$ concentration did not change in both tissues, when compared with control mice. $1,25(\mathrm{OH})_{2} \mathrm{D}_{3}$ was not delectable locally in tissues.

Intestinal $v d r$ expression tended to be decreased by half in $A b c b 1^{-/}$mice compared to control mice (relative expression of $100.0 \pm 20.3 \%$ in control mice vs $51.2 \pm 12.5 \%$ in $A b c b 1^{-/-}$mice), but this difference remained nonsignificant.

\section{Postprandial absorption of $D_{3}$ is increased by $A B C B 1$ deficiency in mice}

The postprandial plasma response in vitamin $\mathrm{D}$ was assessed with vitamin $\mathrm{D}$ dietary form, i.e. $\mathrm{D}_{3} . \mathrm{D}_{3}$ postprandial plasma response was significantly increased in $A b c b 1^{-/-}$mice compared with $A b c b 1^{+/+}$mice after $3 \mathrm{~h}$ of gavage $(+196.2 \%, \mathrm{p}<0.05)$, and after $6 \mathrm{~h}(+59.1 \%, \mathrm{p}<0.05)$ (Figure 3A). Subsequently, the overall postprandial plasma $\mathrm{D}_{3}$ response, expressed as area under the postprandial plasma concentration versus time curves at $0-6 \mathrm{~h}$, tended to be higher in the $A b c b 1^{-/}$animals compared with control mice (Figure 3B). The increase in $\mathrm{D}_{3}$ postprandial response in $\mathrm{Abcbl}^{-/}$mice was more pronounced and became significant after plasma total lipid (i.e. plasma triacylglycerols, phospholipids and cholesterol) adjustment: 3.43 and $6.71 \mu \mathrm{mol} . \mathrm{h} / \mathrm{g}$ of total lipids for $A b c b 1^{-/}$and $A b c b 1^{+/+}$mice, respectively $(\mathrm{p}<0.05$; Figures $3 \mathrm{C}$ and 3D). Finally, the $\mathrm{D}_{3}$ content of the last intestinal fragment (i.e. ileum) of the $A b c b 1^{-/-}$mice, was about two times higher, although non- significantly because of the high variability, than the $\mathrm{D}_{3}$ content of the last fragment of $A b c b 1^{+/+}$mice (Figure 3E).

\section{ABCB1 is involved in the transintestinal excretion of vitamin $D$ in mice}

In order to follow the transintestinal transport of vitamin $\mathrm{D}$, we used $25(\mathrm{OH}) \mathrm{D}_{3}$, which is the main vitamin $\mathrm{D}$ form in the blood compartment. We first measured the apical transfer of $25(\mathrm{OH}) \mathrm{D}_{3}$ through intestinal explants using Ussing chambers. After $30 \mathrm{~min}$, the $25(\mathrm{OH}) \mathrm{D}_{3}$ concentration in the apical compartment was twice more important for the parental explants than for the $A b c b 1^{-/-}$mice jejunum ( $<<0.05$, Figure 4A). A mice intestinal perfusion model was then used to investigate the $25(\mathrm{OH}) \mathrm{D}_{3}$ transintestinal transport in vivo. Results showed a significant decrease in the amounts of plasma $\mathrm{H}^{3}-25(\mathrm{OH}) \mathrm{D}_{3}$ measured in the $A b c b 1^{-/-}$ intestine perfusate after 30, 60 and $120 \mathrm{~min}$, compared with $A b c b 1^{+/+}$mice after 30, 60 and $120 \mathrm{~min}(-$ $33.7 \%$; $-26.1 \%$ and $-25.3 \%$ respectively; $\mathrm{p}<0.005 ; \mathrm{p}<0.05 ; \mathrm{p}<0.005$ ) (Figure $4 \mathrm{~B}$ ). Therefore, the global $25(\mathrm{OH}) \mathrm{D}_{3}$ intestinal excretion after weight adjustment within the 2 hours of experiment was $-36.6 \%$ lower in $A b c b 1^{-/-}$mice, compared with $A b c b 1^{+/+}$mice ( $<<0.005$; Figure $\left.4 \mathrm{C}\right)$.

\section{ABCB1 shows in silico high affinity binding sites for $\mathrm{D}_{3}$ and $25(\mathrm{OH}) \mathrm{D}_{3}$}

We then studied the putative molecular interactions between the protein and $\mathrm{D}_{3}$ or $25(\mathrm{OH}) \mathrm{D}_{3}$ using in silico docking on well-resolved crystal structure of C. elegans Pgp-1 in an open-inward configuration. The most 
favored docked poses for $\mathrm{D}_{3}$ and $25(\mathrm{OH}) \mathrm{D}_{3}$ on Cel-Pgp-1 exhibited both low binding energies scores (-8.9 and $-8.8 \mathrm{kcal} / \mathrm{mol}$, respectively), consistent with ligand-protein interaction of high affinity. The binding sites of the two compounds were proved to be very close to each other and located in the inner chamber delineated by the transmembrane domains of the protein (Figure 5A). The molecular poses revealed favored interactions of vitamin D with several residues on TM1, TM11 and TM12. Of particular interest, the 3hydroxy substituent present on both forms of vitamin D could engage in 3 hydrogen bonds with T1028, G1032, and to a weaker extent L1031, all located on TM12 (Figure 5B and 5C), while the 25-hydroxy group present only in the $25(\mathrm{OH}) \mathrm{D}_{3}$ proved to form 2 additional $\mathrm{H}$-bonds with the Q98 residue (TM1) (Figure 5C). A number of other contact residues such as M1021 and T1025 on TM12 and L990, L993, N994 and Y998 on TM11 engaged hydrophobic interactions with the two forms of vitamin D (Figure 5D).

\section{A SNP in ABCB1 is associated with the fasting plasma $25(\mathrm{OH}) D_{3}$ concentration in a group of healthy male adults}

Subjects carrying the lesser frequent allele at rs 17064, localized in the le 3'-Untranslated Region of $A B C B 1$ gene, displayed a $35.9 \%$ decrease in their $25(\mathrm{OH}) \mathrm{D}_{3}$ status compared with subjects homozygous for the most frequent allele (respectively $35.94 \pm 4.50 \mathrm{nmol} / \mathrm{L}, \mathrm{n}=9$ vs $56.07 \pm 3.00 \mathrm{nmol} / \mathrm{L}, \mathrm{n}=30$; adjusted $\mathrm{p}=0.041$, t-test with Benjamini-Hochberg correction). Of note, 3 other SNPs (rs1045642, rs 17149810, rs2235015) exhibited a significant $p$-value but they did not reach significance following multiple comparison correction. A complete list of the SNPs tested and their respective p-value and adjusted p-value are presented in Table $\mathbf{1}$. 


\section{Discussion}

Given the prominent role of ABCB1 in effluxing a large spectrum of lipophilic compounds, including cholesterol, we considered this transporter as a good candidate that could participate in the turn-over of vitamin D. We thus explored the ABCB1-mediated transport and intestinal export of vitamin $\mathrm{D}$, and we detailed the molecular interactions supporting this process.

We first used the popular Caco-2 TC-7 intestinal cell model, which constitutionally expresses ABCB1 (26). We confirmed that these cells were able to efflux both neo-absorbed $\mathrm{D}_{3}$ and $25(\mathrm{OH}) \mathrm{D}_{3}$ to the apical medium, in line with our previous data $(5,6)$. The fact that the efflux of both vitamin $\mathrm{D}$ forms could be impaired by PSC833, the reference inhibitor of ABCB1 activity, is taken as primary evidence that ABCB1 is involved in this process. Zosuquidar, a third generation ABCB1 specific inhibitor, led to similar results. Finally, KO143, a relative specific inhibitor of $A B C G 2$, impaired $\mathrm{D}_{3}$ efflux but not that of $25(\mathrm{OH}) \mathrm{D}_{3}$, suggestion that $\mathrm{D}_{3}$ efflux may be mediated by other transporters. The significant increase in $\mathrm{D}_{3}$ and $25(\mathrm{OH}) \mathrm{D}_{3}$ efflux and transepithelial secretion in two other cell models overexpressing ABCB1 provides additional evidence on the specific involvement of ABCB1 in vitamin D transport. Finally, direct interaction of $\mathrm{D}_{3}$ and $25(\mathrm{OH}) \mathrm{D}_{3}$ with $\mathrm{HsABCB} 1$ was further confirmed by in vitro experiments showing that both compounds inhibited the ABCB1-verapamil-stimulated ATPase activity.

We then explored vitamin D status in vivo in an $A b c b 1^{-/-}$mouse model lacking both $A b c b 1 a$ and $A b c b 1 b$ genes encoding the two forms of ABCB1 (ABCB1a and ABCB1b) expressed in rodents (27). We observed that fasting plasma $25(\mathrm{OH}) \mathrm{D}_{3}$ and $\mathrm{D}_{3}$ concentrations were significantly increased in $\mathrm{Abcbl^{-/ }}$ mice compared with control animals, supporting a role of $\mathrm{ABCB} 1$ in the elimination of vitamin D. Plasma $1,25(\mathrm{OH})_{2} \mathrm{D}_{3}$ was not modified, which is likely due to its tight regulation process (28). Interestingly, $A b c b 1^{-/-}$mice displayed increased $\mathrm{D}_{3}$ and $25(\mathrm{OH}) \mathrm{D}_{3}$ levels in the brain as well, which is consistent with the important role of $\mathrm{ABCB} 1$ at the blood-brain-barrier level (29). Increased $25(\mathrm{OH}) \mathrm{D}_{3}$ levels were also measured in $A b c b 1^{-/-}$ liver and kidneys compared with organs from control mice where ABCB1 is physiologically expressed (29). $\mathrm{ABCB} 1$ is largely expressed in the gut where it mediates the luminal efflux of its substrates, thereby regulating the intestinal absorption of a broad range of dietary components. At fast, a significant accumulation of both $\mathrm{D}_{3}$ and $25(\mathrm{OH}) \mathrm{D}_{3}$ was observed in $A b c b 1^{-/-}$mouse intestines compared with control intestines. After $\mathrm{a}_{3}$ gavage in oil-in-water emulsion, the lipid-adjusted postprandial plasma $\mathrm{D}_{3}$ response was significantly increased in $A b c b 1^{-/}$mice compared with control animals. This strongly supports that ABCB1 impacts on vitamin D absorption process by secreting back to the intestinal lumen a fraction of neoabsorbed vitamin D. Furthermore, this effect was, at least partly, specific to vitamin D, as it was not driven by a concomitant increase in dietary lipid absorption. Finally, $\mathrm{D}_{3}$ content of the distal intestinal mucosa, where ABCB1 is predominant in control mice (30), tended to be increased in ABCB1-deficient animals, in accordance with a defect in the efflux of vitamin D. 
As ABCB1 is involved in cholesterol transintestinal excretion (9), we further explored its capacity to participate in vitamin D transintestinal secretion as well using ex vivo intestinal explants. The basolateral to apical transfer of $25(\mathrm{OH}) \mathrm{D}_{3}$ was significantly lower when intestinal explants were lacking $\mathrm{ABCB} 1$. The existence of an active intestinal excretion pathway for vitamin D was further reinforced by data obtained in vivo in in situ perfused mice. Indeed, we clearly showed for the first time that when administered by intravenous injection, $25(\mathrm{OH}) \mathrm{D}_{3}$ can be excreted from the plasma compartment to the intestinal lumen. We also showed that this process is mediated, at least partly, by ABCB1.

By using in silico docking approach, we provide computational evidence that the two forms of vitamin D can bind efficiently a close ortholog of human ABCB1. ABCB protein structures and functions are well conserved within all living kingdoms, including nematodes and mammals (31), and the nematode ABCB1, i.e. Cel-Pgp-1, has been previously described to share similar structural features with the mammalian ABCB1 in ligand binding $(22,32)$. We therefore confidently used Cel-Pgp-1 3D structure as relevant model for human $\mathrm{ABCB} 1$ in an open-inward configuration, which is supposed to be the first conformational state recognized by a substrate (21). Both vitamin D forms specifically bound in a region deeply embedded in the transmembrane hydrophobic domains of the transporter. This positioning is consistent with subsequent triggering of the cascade of events that leads to the translocation of the compound out of the cells. Interestingly, similar positioning was found for $\mathrm{D}_{3}$ and $25(\mathrm{OH}) \mathrm{D}_{3}$ on an area corresponding to the multispecific drug binding domain, previously described as the upper binding site in Cel-Pgp-1 (22) and in mammalian ABCB1 (33). The 3 and 4 hydrogen bonds engaged respectively by $\mathrm{D}_{3}$ and $25(\mathrm{OH}) \mathrm{D}_{3}$ with residues on TM1 and on TM12 were consistent with the high-affinity binding of vitamin D on Cel-Pgp-1. Importantly, most of the interacting residues are pointed out as hotspots for drug binding in mammalian $\mathrm{ABCB}$ 1, further validating the relevance of the homology modeling. Interestingly, the hydrophobic TMD11 appeared as a "Velcro®" strap that fixed the molecules on the protein between residues 98 and 1028, further stabilizing the vitamin D in their binding sites, giving high confidence in these poses. Remarkably, the vitamin D binding modes were very similar, in terms of location and interacting residues, to that of the $\mathrm{ABCB} 1$ substrate progesterone (unpublished data), strengthening the idea that, beside transporting many drugs, ABCB1 can also transport steroid derivatives, including vitamin D. Overall, the binding modes as described herein for vitamin D on Cel-Pgp-1, were proven to be compatible with a transport by ABCB1 (21, 22).

Finally, to evaluate whether ABCB1 could play a significant role in vitamin D status in humans, we explored the associations between polymorphisms in $A B C B 1$ and the interindividual variability in $25(\mathrm{OH}) \mathrm{D}_{3}$ concentration in a group of healthy male adults. The observed association between a SNP in the 3 '-untranslated region of $A B C B 1$ (rs17064) and decreased fasting 25(OH)D status strengthens our data obtained with both in vitro and animal models. The untranslated regions at the $3^{\prime}$ end of mRNA transcripts 
are known to exhibit important sequences regulating the fate of mRNA and thus proteosynthesis. A previous study showed that rs 17064 did not alter $A B C B 1$ mRNA stability (34), but further research is needed to evaluate whether this variant can influence $\mathrm{ABCB} 1$ protein function or expression levels through other mechanisms, e.g. microRNA-mediated gene regulation (35). Indeed, miRNAs have been involved in the regulation of $A B C B 1$ mRNA degradation (36). Based on these data, we can speculate that rs17064 affects ABCB1 expression, which may lead to altered vitamin D transport and status. Since SNPs on the microarrays are tag SNPs, i.e. they are highly correlated to neighboring SNPs and therefore represent many unmeasured SNPs located in the same genomic region, it cannot be excluded that rs 17064 is in linkage disequilibrium with the unidentified causal variant (37). However, together with the observation that 2 SNPs in $A B C B 1$ were previously associated with $\mathrm{D}_{3}$ bioavailability in the same group of subjects (23), this result highly suggests that ABCB1 is involved in vitamin D homeostasis in humans by affecting both the net absorption of dietary vitamin D and the net efflux of circulating vitamin D. As gender differences in clearance have been reported for ABCB1 (38) and because estrogens can influence ABCB1 activity (39), the specific effect of $\mathrm{ABCB} 1$ on vitamin $\mathrm{D}$ status in women remains to be evaluated. Interestingly, 1,25-dihydroxyvitamin $\mathrm{D}_{3}$ was previously shown to modulate $A B C B 1$ expression via the Vitamin D Receptor VDR in human intestine (40), which further emphasizes the close link between ABCB1 and vitamin D turnover. Our data showed that $v d r$ intestinal expression tended to be downregulated by in $A b c b 1^{-/}$mice compared with $A b c b 1^{+/+}$mice. The regulation of vitamin $\mathrm{D}$ intestinal efflux by intestinal VDR is thus another point of interest that would require specific research.

Our data highlight for the first time a new ABCB1-mediated pathway for vitamin D cellular efflux, as well as for vitamin D export from the bloodstream to the intestinal lumen.

These data reinforce the idea that $\mathrm{ABCB} 1$ can control the transport of important dietary lipid components such as vitamin D. The large variability of intestinal $A B C B 1$ expression levels (41) may thus participate in the variability also observed regarding vitamin D status. Since ABCB1 activity can be simultaneously regulated by many dietary components, drugs or polymorphisms, deciphering further the contribution of $\mathrm{ABCB} 1$ to vitamin D excretion balance will help to better apprehend vitamin D metabolism.

The new metabolic excretion pathway highlighted here can be described as a "TransIntestinal fat-soluble Micronutrient Excretion" (TIME), which may have a significant impact on fat-soluble vitamin homeostasis. This novel finding raises several questions. Firstly, we cannot exclude that transporters other than ABCB1 are involved in neo-absorbed vitamin D efflux and in TIME. Since TICE is more affected by the deletion of other cholesterol transporters than by ABCB1 deficiency in mice $(9,42,43)$, it would be interesting to determine the contribution of additional membrane proteins to TIME. Secondly, the physiological relevance of such excretion pathway remains to be evaluated. Given that several ABCB1 endogenous ligands 
(cholesterol, steroids, xenobiotics) are present in the organism at rather high concentrations compared with vitamin D, neo-absorbed vitamin efflux or TIME may be active in situation of oral vitamin D supply only. The capacity of vitamin D to interact at physiological concentrations with ABCB1 thus remains to be fully characterized. Finally, TICE is currently largely investigated because it might be an interesting therapeutic target for increasing cholesterol disposal with the feces (44). It would consequently be of primary interest to assess whether TICE activation can lead to a concomitant increase in TIME that would potentially be deleterious for patients. 


\section{Acknowledgements:}

We acknowledge Marion Nowicki and Lea Lasvaux for technical contributions, as well as Marion David for sharing knowledge on docking experiments.

Marielle Margier received a doctoral fellowship (2015-2018) from Region PACA (France) in partnership with the Centre Technique de Conservation des Produits Alimentaires (CTCPA Avignon, France). This work was partly supported by a Research Price from the French Nutrition Society (SFN).

\section{Author contributions:}

All authors have declared that no conflict of interest exists. ER and AL designed the research project with the participation of XC; MM and CL performed in vitro experiments; MM and CLM performed in vivo experiments; MM and CD performed LC-MS analyses; ChD and PB performed SNP analysis; FA performed docking experiments; all authors participated in analysis and interpretation of data; $\mathrm{MM}$ and $\mathrm{ChD}$ did the statistical analyses; ER and AL drafted the manuscript; XC did a critical revision of the manuscript; all authors have read and approved the final manuscript; ER and AL have primary responsibility for the final content of the manuscript. 


\section{References}

1. Wimalawansa, S. J. (2011) Vitamin D: an essential component for skeletal health. Ann N Y Acad Sci 1240, E1-12

2. Holick, M. F. (2017) The vitamin D deficiency pandemic: Approaches for diagnosis, treatment and prevention. Rev Endocr Metab Disord 18, 153-165

3. Bikle, D. D. (2014) Vitamin D metabolism, mechanism of action, and clinical applications. Chemistry \& biology 21, 319-329

4. Hollander, D., Muralidhara, K. S., and Zimmerman, A. (1978) Vitamin D-3 intestinal absorption in vivo: influence of fatty acids, bile salts, and perfusate $\mathrm{pH}$ on absorption. Gut 19, 267-272

5. Reboul, E., Goncalves, A., Comera, C., Bott, R., Nowicki, M., Landrier, J. F., Jourdheuil-Rahmani, D., Dufour, C., Collet, X., and Borel, P. (2011) Vitamin D intestinal absorption is not a simple passive diffusion: evidences for involvement of cholesterol transporters. Mol Nutr Food Res 55, 691-702

6. Desmarchelier, C., Margier, M., Preveraud, D. P., Nowicki, M., Rosilio, V., Borel, P., and Reboul, E. (2017) Comparison of the Micellar Incorporation and the Intestinal Cell Uptake of Cholecalciferol, 25Hydroxycholecalciferol and 1-alpha-Hydroxycholecalciferol. Nutrients 9

7. Sharom, F. J. (2011) The P-glycoprotein multidrug transporter. Essays Biochem 50, 161-178

8. Uhr, M., Holsboer, F., and Muller, M. B. (2002) Penetration of endogenous steroid hormones corticosterone, cortisol, aldosterone and progesterone into the brain is enhanced in mice deficient for both mdr1a and mdr1b P-glycoproteins. J Neuroendocrinol 14, 753-759

9. Le May, C., Berger, J. M., Lespine, A., Pillot, B., Prieur, X., Letessier, E., Hussain, M. M., Collet, X., Cariou, B., and Costet, P. (2013) Transintestinal cholesterol excretion is an active metabolic process modulated by PCSK9 and statin involving ABCB1. Arterioscler Thromb Vasc Biol 33, 1484-1493

10. Goncalves, A., Gleize, B., Roi, S., Nowicki, M., Dhaussy, A., Huertas, A., Amiot, M. J., and Reboul, E. (2013) Fatty acids affect micellar properties and modulate vitamin D uptake and basolateral efflux in Caco2 cells. J Nutr Biochem 24, 1751-1757 
11. Goncalves, A., Margier, M., Tagliaferri, C., Lebecque, P., George, S., Wittrant, Y., Coxam, V., Amiot, M. J., and Reboul, E. (2016) Pinoresinol of olive oil decreases vitamin D intestinal absorption. Food Chem 206, 234-238

12. Borel, P., Lietz, G., Goncalves, A., Szabo de Edelenyi, F., Lecompte, S., Curtis, P., Goumidi, L., Caslake, M. J., Miles, E. A., Packard, C., Calder, P. C., Mathers, J. C., Minihane, A. M., Tourniaire, F., KesseGuyot, E., Galan, P., Hercberg, S., Breidenassel, C., Gonzalez Gross, M., Moussa, M., Meirhaeghe, A., and Reboul, E. (2013) CD36 and SR-BI Are Involved in Cellular Uptake of Provitamin A Carotenoids by Caco2 and HEK Cells, and Some of Their Genetic Variants Are Associated with Plasma Concentrations of These Micronutrients in Humans. J Nutr 143, 448-456

13. Goncalves, A., Margier, M., Roi, S., Collet, X., Niot, I., Goupy, P., Caris-Veyrat, C., and Reboul, E. (2014) Intestinal scavenger receptors are involved in vitamin K1 absorption. J Biol Chem 289, 30743-30752 14. Reboul, E., Abou, L., Mikail, C., Ghiringhelli, O., Andre, M., Portugal, H., Jourdheuil-Rahmani, D., Amiot, M. J., Lairon, D., and Borel, P. (2005) Lutein transport by Caco-2 TC-7 cells occurs partly by a facilitated process involving the scavenger receptor class B type I (SR-BI). Biochem J 387, 455-461

15. Sarkadi, B., Price, E. M., Boucher, R. C., Germann, U. A., and Scarborough, G. A. (1992) Expression of the human multidrug resistance cDNA in insect cells generates a high activity drug-stimulated membrane ATPase. Journal of Biological Chemistry 267, 4854-4858

16. Menez, C., Sutra, J. F., Prichard, R., and Lespine, A. (2012) Relative neurotoxicity of ivermectin and moxidectin in Mdr1ab (-/-) mice and effects on mammalian GABA(A) channel activity. PLoS Negl Trop Dis 6, e1883

17. Goncalves, A., Roi, S., Nowicki, M., Niot, I., and Reboul, E. (2014) Cluster-determinant 36 (CD36) impacts on vitamin E postprandial response. Mol Nutr Food Res 58, 2297-2306

18. Wang, Z., Senn, T., Kalhorn, T., Zheng, X. E., Zheng, S., Davis, C. L., Hebert, M. F., Lin, Y. S., and Thummel, K. E. (2011) Simultaneous measurement of plasma vitamin D(3) metabolites, including 4beta,25dihydroxyvitamin D(3), using liquid chromatography-tandem mass spectrometry. Anal Biochem 418, 126- 
19. Hedman, C. J., Wiebe, D. A., Dey, S., Plath, J., Kemnitz, J. W., and Ziegler, T. E. (2014) Development of a sensitive LC/MS/MS method for vitamin D metabolites: 1,25 Dihydroxyvitamin D2\&3 measurement using a novel derivatization agent. Journal of chromatography. B, Analytical technologies in the biomedical and life sciences 953-954, 62-67

20. Xue, Y., He, X., Li, H. D., Deng, Y., Yan, M., Cai, H. L., Tang, M. M., Dang, R. L., and Jiang, P. (2015) Simultaneous Quantification of 25-Hydroxyvitamin D3 and 24,25-Dihydroxyvitamin D3 in Rats Shows Strong Correlations between Serum and Brain Tissue Levels. Int J Endocrinol 2015, 296531

21. Jin, M. S., Oldham, M. L., Zhang, Q., and Chen, J. (2012) Crystal structure of the multidrug transporter P-glycoprotein from Caenorhabditis elegans. Nature 490, 566-569

22. David, M. A., Orlowski, S., Prichard, R. K., Hashem, S., Andre, F., and Lespine, A. (2016) In silico analysis of the binding of anthelmintics to Caenorhabditis elegansP-glycoprotein 1. Int J Parasitol Drugs Drug Resist 6, 299-313

23. Desmarchelier, C., Borel, P., Goncalves, A., Kopec, R., Nowicki, M., Morange, S., Lesavre, N., Portugal, H., and Reboul, E. (2016) A Combination of Single-Nucleotide Polymorphisms Is Associated with Interindividual Variability in Cholecalciferol Bioavailability in Healthy Men. J Nutr 146, 2421-2428

24. Desmarchelier, C., Martin, J. C., Planells, R., Gastaldi, M., Nowicki, M., Goncalves, A., Valero, R., Lairon, D., and Borel, P. (2014) The postprandial chylomicron triacylglycerol response to dietary fat in healthy male adults is significantly explained by a combination of single nucleotide polymorphisms in genes involved in triacylglycerol metabolism. J Clin Endocrinol Metab 99, E484-488

25. Storey, J. D. (2002) A direct approach to false discovery rates. Journal of the Royal Statistical Society: Series B (Statistical Methodology) 64, 479-498

26. Collett, A., Tanianis-Hughes, J., Hallifax, D., and Warhurst, G. (2004) Predicting P-glycoprotein effects on oral absorption: correlation of transport in Caco-2 with drug pharmacokinetics in wild-type and mdr1a(-/-) mice in vivo. Pharm Res 21, 819-826

27. Schinkel, A. H., Smit, J. J., van Tellingen, O., Beijnen, J. H., Wagenaar, E., van Deemter, L., Mol, C. A., van der Valk, M. A., Robanus-Maandag, E. C., te Riele, H. P., and et al. (1994) Disruption of the mouse 
mdrla P-glycoprotein gene leads to a deficiency in the blood-brain barrier and to increased sensitivity to drugs. Cell 77, 491-502

28. Anderson, P. H., O’Loughlin, P. D., May, B. K., and Morris, H. A. (2004) Determinants of circulating 1, 25-dihydroxyvitamin D3 levels: the role of renal synthesis and catabolism of vitamin D. The Journal of steroid biochemistry and molecular biology 89, 111-113

29. Cui, Y. J., Cheng, X., Weaver, Y. M., and Klaassen, C. D. (2009) Tissue distribution, gender-divergent expression, ontogeny, and chemical induction of multidrug resistance transporter genes (Mdr1a, Mdr1b, Mdr2) in mice. Drug Metab Dispos 37, 203-210

30. MacLean, C., Moenning, U., Reichel, A., and Fricker, G. (2008) Closing the gaps: a full scan of the intestinal expression of p-glycoprotein, breast cancer resistance protein, and multidrug resistance-associated protein 2 in male and female rats. Drug Metab Dispos 36, 1249-1254

31. Higgins, C. F. (1992) ABC transporters: from microorganisms to man. Annu Rev Cell Biol 8, 67-113

32. David, M. A., Lebrun, C., Duguet, T., Talmont, F., Beech, R., Orlowski, S., Andre, F., Prichard, R., and Lespine, A. (2018) Structural model, functional modulation by ivermectin and tissue localization of Haemonchus contortus P-glycoprotein-13. Int J Parasitol Drugs Drug Resist in press

33. Garrigues, A., Loiseau, N., Delaforge, M., Ferte, J., Garrigos, M., Andre, F., and Orlowski, S. (2002) Characterization of two pharmacophores on the multidrug transporter P-glycoprotein. Mol Pharmacol 62, 1288-1298

34. Gow, J. M., Chinn, L. W., and Kroetz, D. L. (2008) The effects of ABCB1 3'-untranslated region variants on mRNA stability. Drug Metab Dispos 36, 10-15

35. Moszyńska, A., Gebert, M., Collawn, J. F., and Bartoszewski, R. (2017) SNPs in microRNA target sites and their potential role in human disease. Open Biology 7, 170019

36. Zhu, H., Wu, H., Liu, X., Evans, B. R., Medina, D. J., Liu, C. G., and Yang, J. M. (2008) Role of MicroRNA miR-27a and miR-451 in the regulation of MDR1/P-glycoprotein expression in human cancer cells. Biochem Pharmacol 76, 582-588 
37. Schaid, D. J., Chen, W., and Larson, N. B. (2018) From genome-wide associations to candidate causal variants by statistical fine-mapping. Nat Rev Genet 19, 491-504

38. Ellen, K.-S. M., R., B. C., Jill, S., and B., S. J. (2000) Faster clearance of sustained release verapamil in men versus women: Continuing observations on sex-specific differences after oral administration of verapamil. Clinical Pharmacology \& Therapeutics 68, 286-292

39. Kim, W. Y., and Benet, L. Z. (2004) P-glycoprotein (P-gp/MDR1)-Mediated Efflux of Sex-Steroid Hormones and Modulation of P-gp Expression In Vitro. Pharmaceutical Research 21, 1284-1293

40. Tachibana, S., Yoshinari, K., Chikada, T., Toriyabe, T., Nagata, K., and Yamazoe, Y. (2009) Involvement of Vitamin D receptor in the intestinal induction of human ABCB1. Drug Metab Dispos 37, 1604-1610

41. Lindell, M., Karlsson, M. O., Lennernas, H., Pahlman, L., and Lang, M. A. (2003) Variable expression of CYP and Pgp genes in the human small intestine. European journal of clinical investigation 33, 493-499 42. van der Veen, J. N., van Dijk, T. H., Vrins, C. L., van Meer, H., Havinga, R., Bijsterveld, K., Tietge, U. J., Groen, A. K., and Kuipers, F. (2009) Activation of the liver X receptor stimulates trans-intestinal excretion of plasma cholesterol. J Biol Chem 284, 19211-19219

43. Jakulj, L., van Dijk, T. H., de Boer, J. F., Kootte, R. S., Schonewille, M., Paalvast, Y., Boer, T., Bloks, V. W., Boverhof, R., Nieuwdorp, M., Beuers, U. H., Stroes, E. S., and Groen, A. K. (2016) Transintestinal Cholesterol Transport Is Active in Mice and Humans and Controls Ezetimibe-Induced Fecal Neutral Sterol Excretion. Cell Metab 24, 783-794

44. Reeskamp, L. F., Meessen, E. C. E., and Groen, A. K. (2018) Transintestinal cholesterol excretion in humans. Curr Opin Lipidol 29, 10-17 
Table

Table 1. List of the SNPs in $A B C B 1$ whose association with fasting plasma $25(\mathrm{OH}) \mathrm{D}_{3}$ concentration was tested in a group of $\mathbf{3 9}$ healthy male adults.

\begin{tabular}{ccc}
\hline SNP rs number & P-value & Adjusted p-value \\
\hline rs17064 & 0.002 & 0.042 \\
rs1045642 & 0.011 & 0.105 \\
rs17149810 & 0.015 & 0.105 \\
rs2235015 & 0.034 & 0.179 \\
rs2235023 & 0.065 & 0.237 \\
rs12539936 & 0.079 & 0.237 \\
rs4148807 & 0.079 & 0.237 \\
rs2178658 & 0.103 & 0.270 \\
rs11772987 & 0.213 & 0.497 \\
rs4148737 & 0.239 & 0.502 \\
rs2235033 & 0.294 & 0.561 \\
rs4148732 & 0.541 & 0.855 \\
rs1202179 & 0.562 & 0.855 \\
rs1211152 & 0.605 & 0.855 \\
rs17327624 & 0.659 & 0.855 \\
rs1922240 & 0.679 & 0.855 \\
rs9282564 & 0.692 & 0.855 \\
rs10264990 & 0.743 & 0.867 \\
rs868755 & 0.849 & 0.916 \\
rs4148733 & 0.872 & 0.916 \\
rs2188526 & 0.934 & 0.934 \\
\hline
\end{tabular}




\section{Figure legends}

\section{Figure 1: $A B C B 1$ involvement in vitamin $D$ apical efflux in epithelial cell models.}

(A-C) Apical efflux of $\mathrm{D}_{3}$ and $25(\mathrm{OH}) \mathrm{D}_{3}$ by Caco-2 TC7 differentiated cell monolayers. Cells were charged overnight with vitamin D before efflux to mixed micelles was measured in the absence (white bar) or presence (black bar) of valspodar 0.1-5 $\mu \mathrm{M}$ (A), zosuquidar $1 \mu \mathrm{M}$ (B) or KO143 $1 \mu \mathrm{M}(\mathrm{C})$. Vitamin D efflux was estimated by the amount of vitamin found in the apical medium and expressed as a percentage of the amount vitamin D taken up by the cells (i.e vitamin D found in the medium plus vitamin D remaining in the cells at the end of the experiment).

(D) Apical efflux of $\mathrm{D}_{3}$ and $25(\mathrm{OH}) \mathrm{D}_{3}$ by Griptite cells transfected or not with $A B C B 1$. Cells were transfected with either an empty pCMV plasmid (०) or with a pCMV plasmid containing $A B C B 1(\bullet)$. The cell monolayers received overnight vitamin D $10 \mu \mathrm{M}$ before efflux was measured at $2 \mathrm{~h}$ and $4 \mathrm{~h}$. Vitamin D efflux was estimated by the amount of vitamin D found in the efflux medium and expressed as a percentage of the amount of vitamin D taken up by the cells (i.e. vitamin D found in the medium at $2 \mathrm{~h}$ plus vitamin $\mathrm{D}$ found in the medium at $4 \mathrm{~h}$ plus vitamin $\mathrm{D}$ found in the cells at the end of the experiment).

(E) Transcellular efflux of $\mathrm{D}_{3}$ and $25(\mathrm{OH}) \mathrm{D}_{3}$ by MDCK-II cells overexpressing $A B C B 1(\bullet)$ compared with control cells (०). The basolateral side of the cell monolayers received media enriched with $10 \mu \mathrm{M}$ vitamin D. Two sequential samples were taken after $2 \mathrm{~h}$ and $4 \mathrm{~h}$ from the apical side. Vitamin D efflux was estimated by the amount of vitamin found in the apical and expressed as a percentage of the amount vitamin D initially delivered at the basolateral side.

(F) Modulation of basal and verapamil-stimulated ABCB1 ATPase activity by $\mathrm{D}_{3}$ and $25(\mathrm{OH}) \mathrm{D}_{3}$. Left panel: ABCB1 ATPase activity was measured in membranes of Sf9 insect cells expression human $A B C B 1$, in absence (control) or in the presence of $40 \mu \mathrm{M} \mathrm{D}_{3}$ or $25(\mathrm{OH}) \mathrm{D}_{3}$. Right panel : The verapamil-stimulatedATPase activity of ABCB1 was determined in the presence of verapamil $5 \mu \mathrm{M}$ (concentration giving the maximal stimulation), in absence (control) or in the presence of $40 \mu \mathrm{M} \mathrm{D}_{3}$ or $25(\mathrm{OH}) \mathrm{D}_{3}$.

Data are mean \pm SEM of 3 assays. ${ }^{*} p<0.05$ when compared with the control cells.

\section{Figure 2: Plasma vitamin D concentration and postprandial plasma vitamin D response to vitamin D} gavage in $\mathrm{Abcb1}^{+/+}$and $\mathrm{Abcb1^{-/ } \text { mice. }}$

(A) Fasting plasma $\mathrm{D}_{3}, 25(\mathrm{OH}) \mathrm{D}_{3}$ and $1,25(\mathrm{OH})_{2} \mathrm{D}_{3}$ concentrations in $A b c b 1^{+/+}(+/+; \mathrm{n}=9)$ and $A b c b 1^{-/ /}(-/-$; $\mathrm{n}=9)$ mice.

(B) Fasting intestinal $\mathrm{D}_{3}$ and $25(\mathrm{OH}) \mathrm{D}_{3}$ concentrations in $A b c b 1^{+/+}(+/+)$and $A b c b 1^{-/-}(-/-)$mice $\left(\mathrm{n}=3\right.$ for $\mathrm{D}_{3}$ and $\mathrm{n}=4$ for $\left.25(\mathrm{OH}) \mathrm{D}_{3}\right)$. 
(C) Brain $\mathrm{D}_{3}$ and $25(\mathrm{OH}) \mathrm{D}_{3}$ concentrations in $A b c b 1^{+/+}(+/+)$and $A b c b 1^{-/-}(-/-)$mice $\left(\mathrm{n}=9\right.$ for $\mathrm{D}_{3}$ and $\mathrm{n}=5$ for $\left.25(\mathrm{OH}) \mathrm{D}_{3}\right)$.

(D) Kidney $\mathrm{D}_{3}$ and $25(\mathrm{OH}) \mathrm{D}_{3}$ concentration in $A b c b 1^{+/+}(+/+)$and $A b c b 1^{-/-}(-/-)$mice (n= 4 per group).

(E) Liver $\mathrm{D}_{3}$ and $25(\mathrm{OH}) \mathrm{D}_{3}$ concentration in $A b c b 1^{+/+}(+/+)$and $A b c b 1^{-/-}(-/-)$mice ( $\mathrm{n}=4$ per group). Data are mean \pm SEM. $* \mathrm{p}<0.05 ; * * \mathrm{p}<0.01 ; * * * \mathrm{p}<0.001$ when compared with the $A b c b 1^{+/+}$mice.

\section{Figure 3: Postprandial plasma vitamin $D$ response to vitamin $D$ gavage and vitamin $D$ intestinal} content in $\mathrm{Abcb1}^{+/+}$and $\mathrm{Abcb1^{-/ }}$ mice.

(A) The mice were force-fed with $\mathrm{D}_{3}$-rich emulsion, and plasma samples were collected every $1.5 \mathrm{~h}$ during a period of 6 h. Postprandial plasma $\mathrm{D}_{3}$ responses in $A b c b 1^{+/+}(\circ ; \mathrm{n}=5)$ and $A b c b 1^{-/-}(\bullet ; \mathrm{n}=4)$ mice.

(C) Postprandial plasma $\mathrm{D}_{3}$ responses adjusted for plasma total lipids (cholesterol plus phospholipids plus triacylglycerols) in $A b c b 1^{+/+}(\circ ; \mathrm{n}=4)$ and $A b c b 1^{-/-}(\bullet ; \mathrm{n}=4)$ mice.

(B-D) Corresponding areas under the curves at 0-6 $\mathrm{h}$.

(E) $\mathrm{D}_{3}$ content of $A b c b 1^{+/+}$and $A b c b 1^{-/}$mice intestinal fragments after force-feeding with a $\mathrm{D}_{3}$-enriched emulsion. $6 \mathrm{~h}$ after force-feeding with a $\mathrm{D}_{3}$-enriched emulsion, intestines from $A b c b 1^{+/+}$and $A b c b 1^{-/-}$mice were harvested and cut into fragments before their $\mathrm{D}_{3}$ content was assessed. Data are means $\pm \mathrm{SEM}$. * $\mathrm{p}<0.05$ when compared with the $A b c b 1^{+/+}$mice.

\section{Figure 4: Vitamin D transintestinal excretion by $A b c b 1^{+/+}$and $A b c b 1^{-/}$mouse intestine.}

(A) Transintestinal $25(\mathrm{OH}) \mathrm{D}_{3}$ excretion measured by using Ussing chambers. $A b c b 1^{+/+}(\circ ; \mathrm{n}=3)$ and $A b c b 1^{-}$ ${ }^{-}(\bullet ; \mathrm{n}=3)$ mice jejunum explants were mounted on Ussing Chambers. $25(\mathrm{OH}) \mathrm{D}_{3} 10 \mu \mathrm{M}$ was added to Krebs/glucose buffer with $1 \%$ of BSA free fatty in the basolateral chamber. The transintestinal $25(\mathrm{OH}) \mathrm{D}_{3}$ excretion was determined after $15 \mathrm{~min}$ and $30 \mathrm{~min}$ by measuring the appearance of $25(\mathrm{OH}) \mathrm{D}_{3}$ in the apical chamber filled with Krebs buffer enriched with $25(\mathrm{OH}) \mathrm{D}_{3}$ acceptors (micelles).

(B) Transintestinal ${ }^{3} \mathrm{H}-25(\mathrm{OH}) \mathrm{D}_{3}$ excretion using in situ perfusion. Mouse duodenum was perfused with Krebs supplemented with taurocholate-phosphatidylcholine micelles. ${ }^{3} \mathrm{H}-25(\mathrm{OH}) \mathrm{D}_{3}$ was injected to $A b c b 1^{+/+}$mice $(\circ ; \mathrm{n}=7)$ and $A b c b 1^{-/-}$mice $(\bullet ; \mathrm{n}=9)$ by the penis vein. Samples of the perfusate were taken and the ${ }^{3} \mathrm{H}-25(\mathrm{OH}) \mathrm{D}_{3}$ content was measured at 30, 60 and $120 \mathrm{~min}$.

(C) Transintestinal ${ }^{3} \mathrm{H}-25(\mathrm{OH}) \mathrm{D}_{3}$ excretion of $A b c b 1^{+/+}$mice (white bar) and $A b c b 1^{-/-}$mice (black bar) after weight adjustment after $2 \mathrm{~h}$.

Data are means \pm SEM. ${ }^{*} \mathrm{p}<0.05 ; * * \mathrm{p}<0.01$ when compared with $A b c b 1^{+/+}$mice.

Figure 5: $\mathrm{D}_{3}$ and 25(OH)D $\mathrm{D}_{3}$ docking positions on the ABCB1 Cel-Pgp-1. 
(A) Ribbon diagram of the 3D structure of Cel-Pgp-1 showing the binding site of the two vitamin D compounds. Vitamin D views correspond to poses of the lowest energy clusters in VDW atom drawing. $\mathrm{D}_{3}$ is colored in blue, $25(\mathrm{OH}) \mathrm{D}_{3}$ in red, Cel-Pgp-1 in cyan (N-term) and yellow (C-term). TM(D), transmembrane (domains); NBD1 and 2, nucleotide binding domains).

(B) $\mathrm{D}_{3}$ structure and lateral view of $\mathrm{D}_{3}$ pose (AutoDock binding energy: $-8.68 \mathrm{kcal} / \mathrm{mol}$ ).

(C) $25(\mathrm{OH}) \mathrm{D}_{3}$ structure and lateral view of $1^{\text {st }}$ cluster pose (binding energy: $-8.76 \mathrm{kcal} / \mathrm{mol}$ ) (TM1 bearing Q98 in red, TM12 bearing T1028 and G1032 in purple).

(D) Detailed view of $\mathrm{D}_{3}$ binding to Cel-Pgp-1, pointing out the H-bond and hydrophobic interactions engaged with residues on TM11 and TM12 helixes, hotspots in red. 

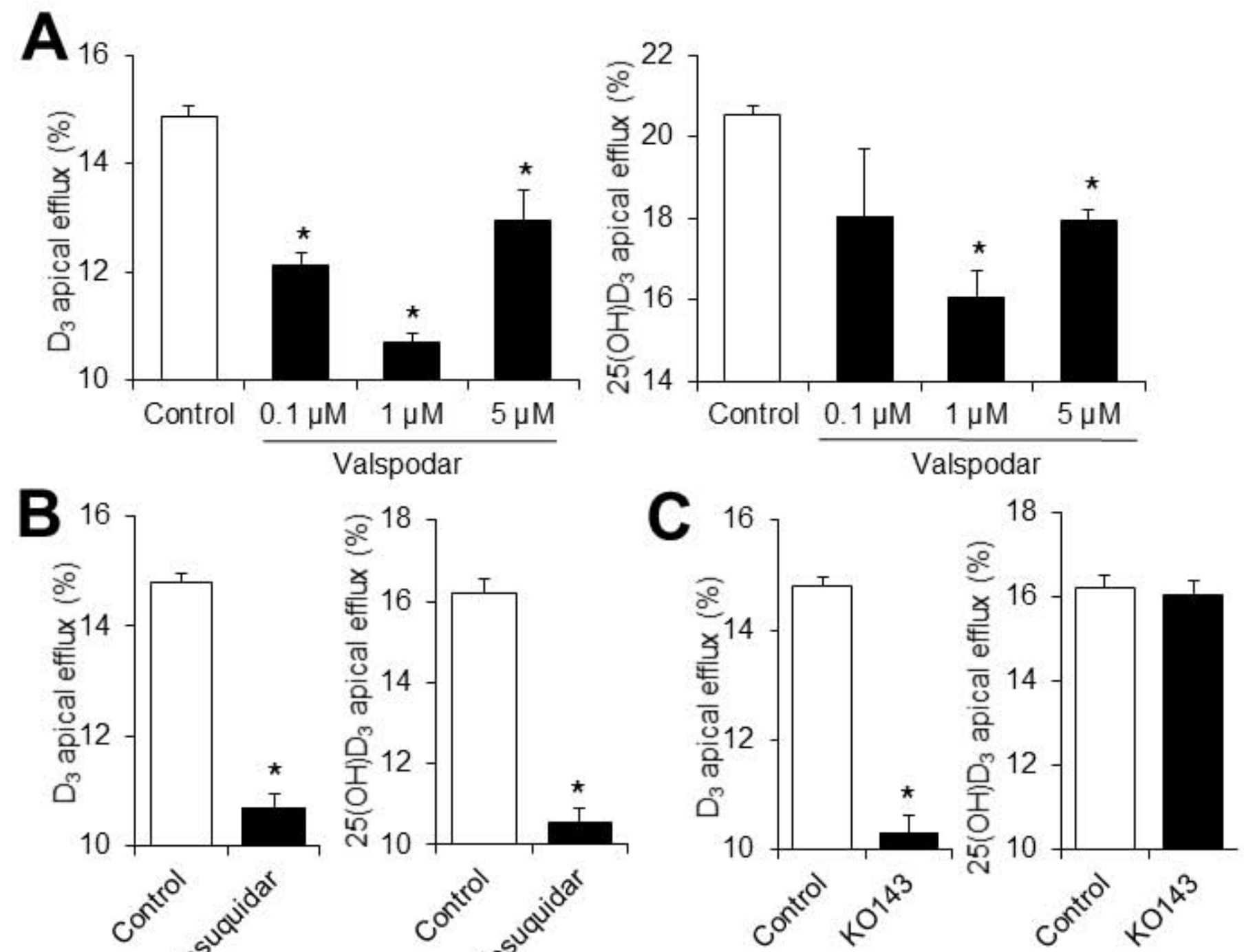

D
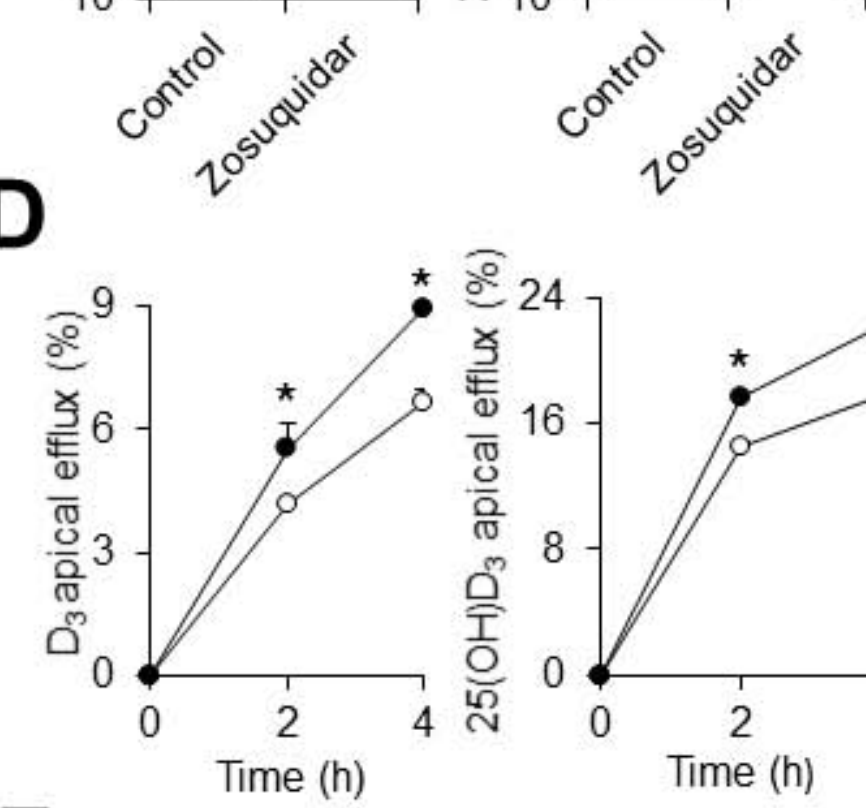

F
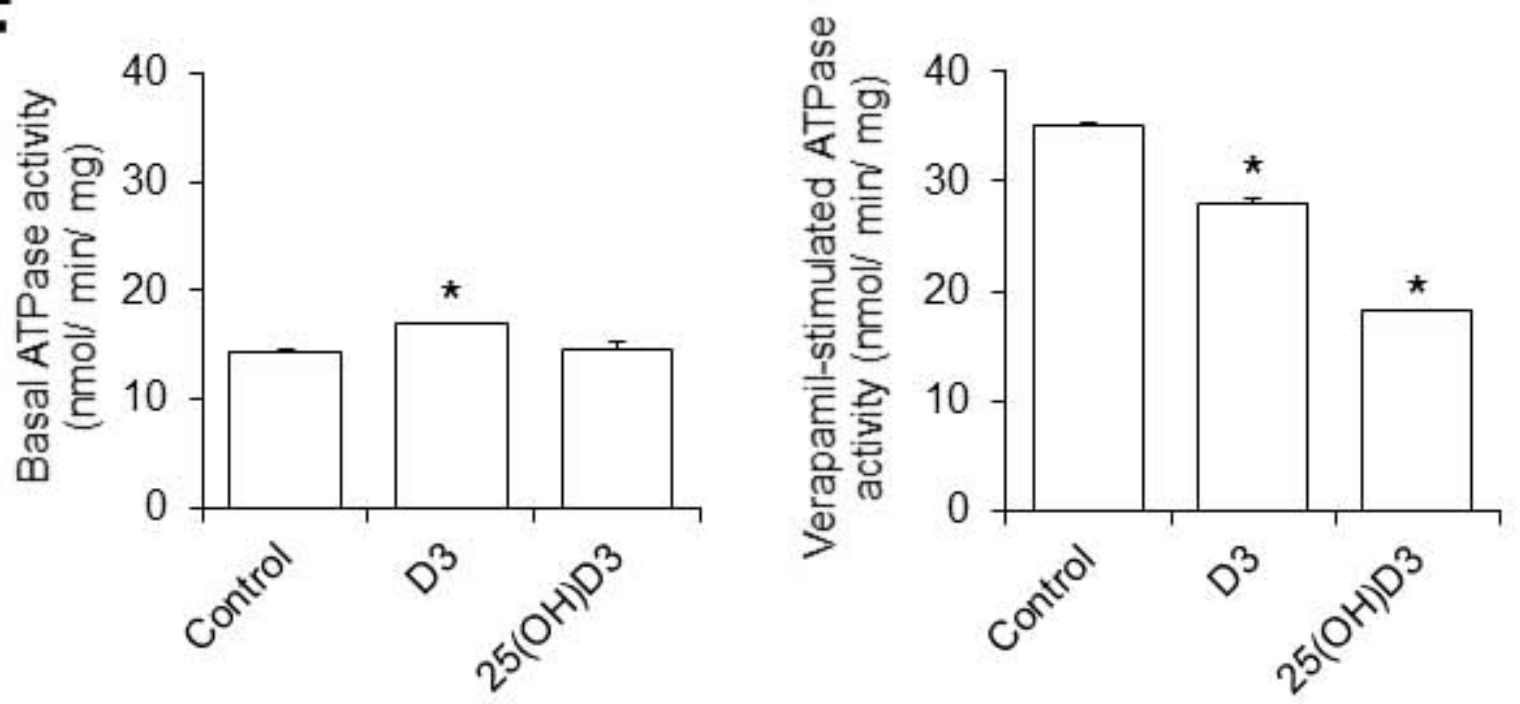
A
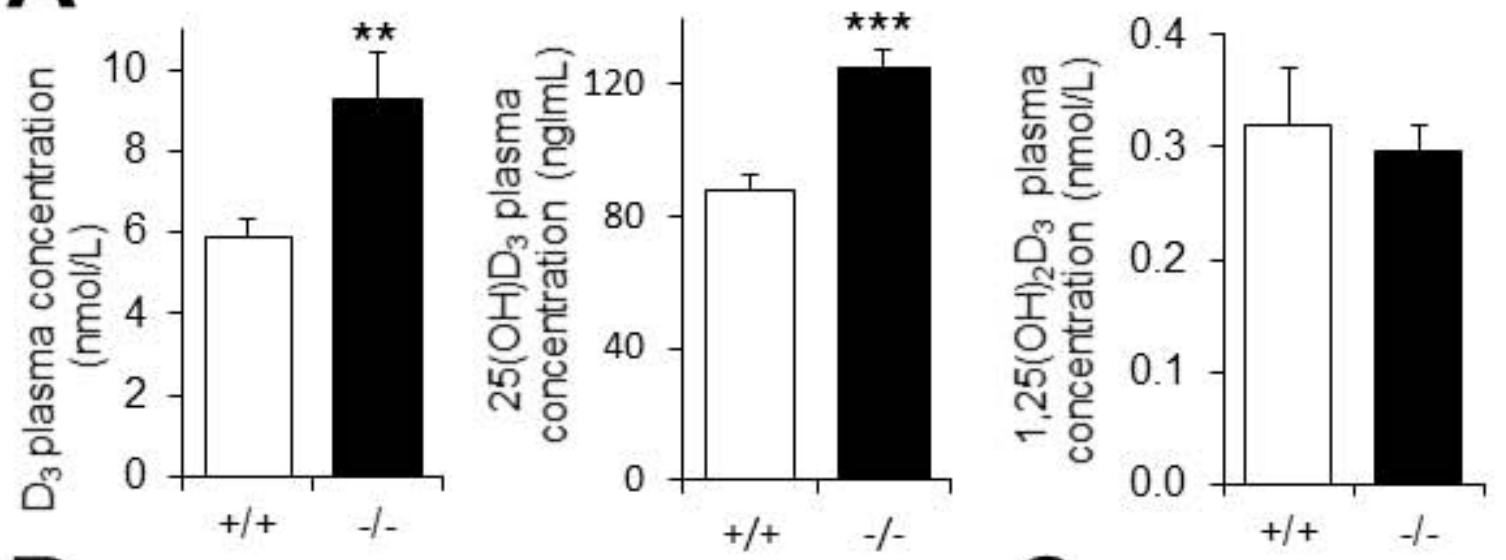

B
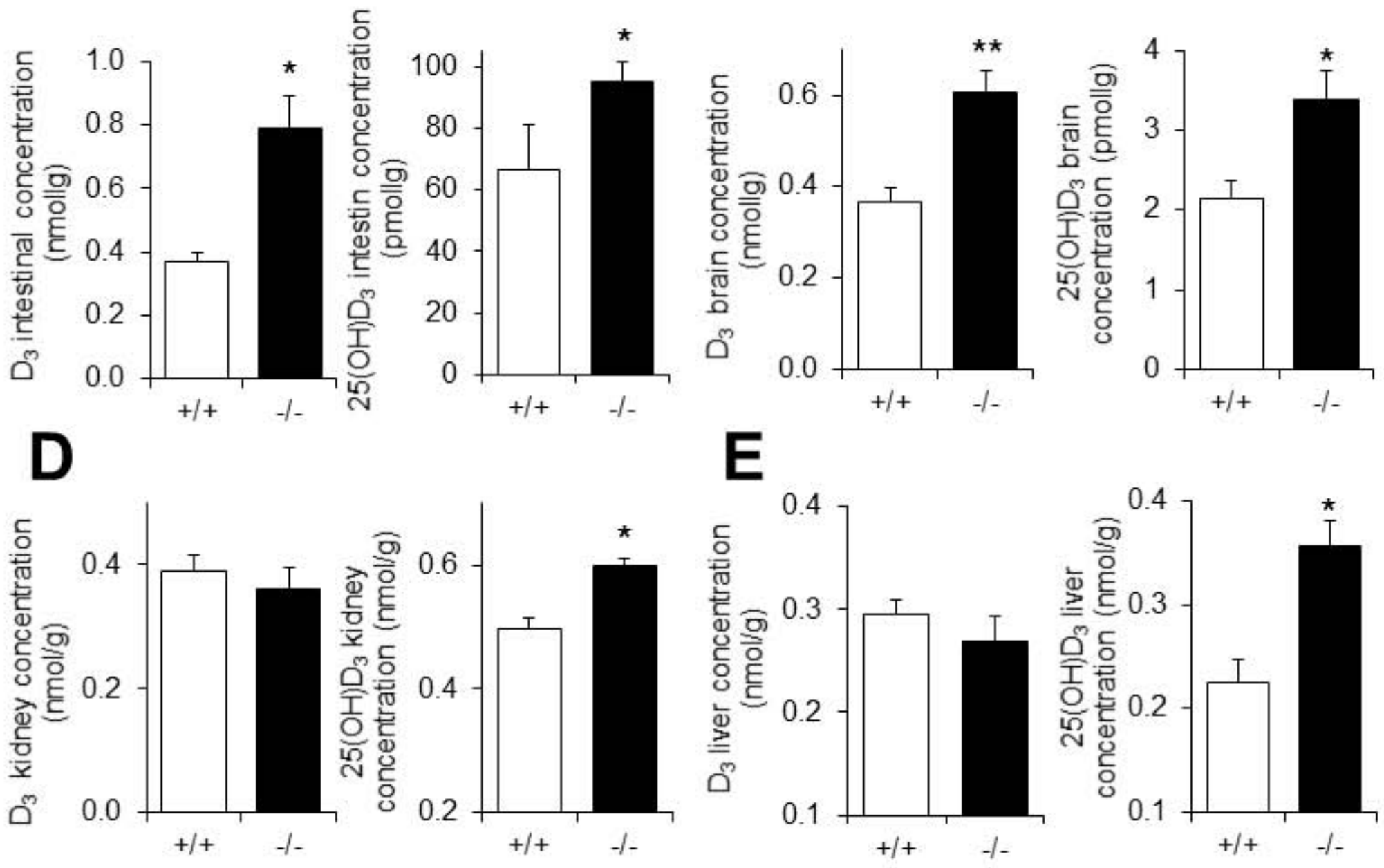

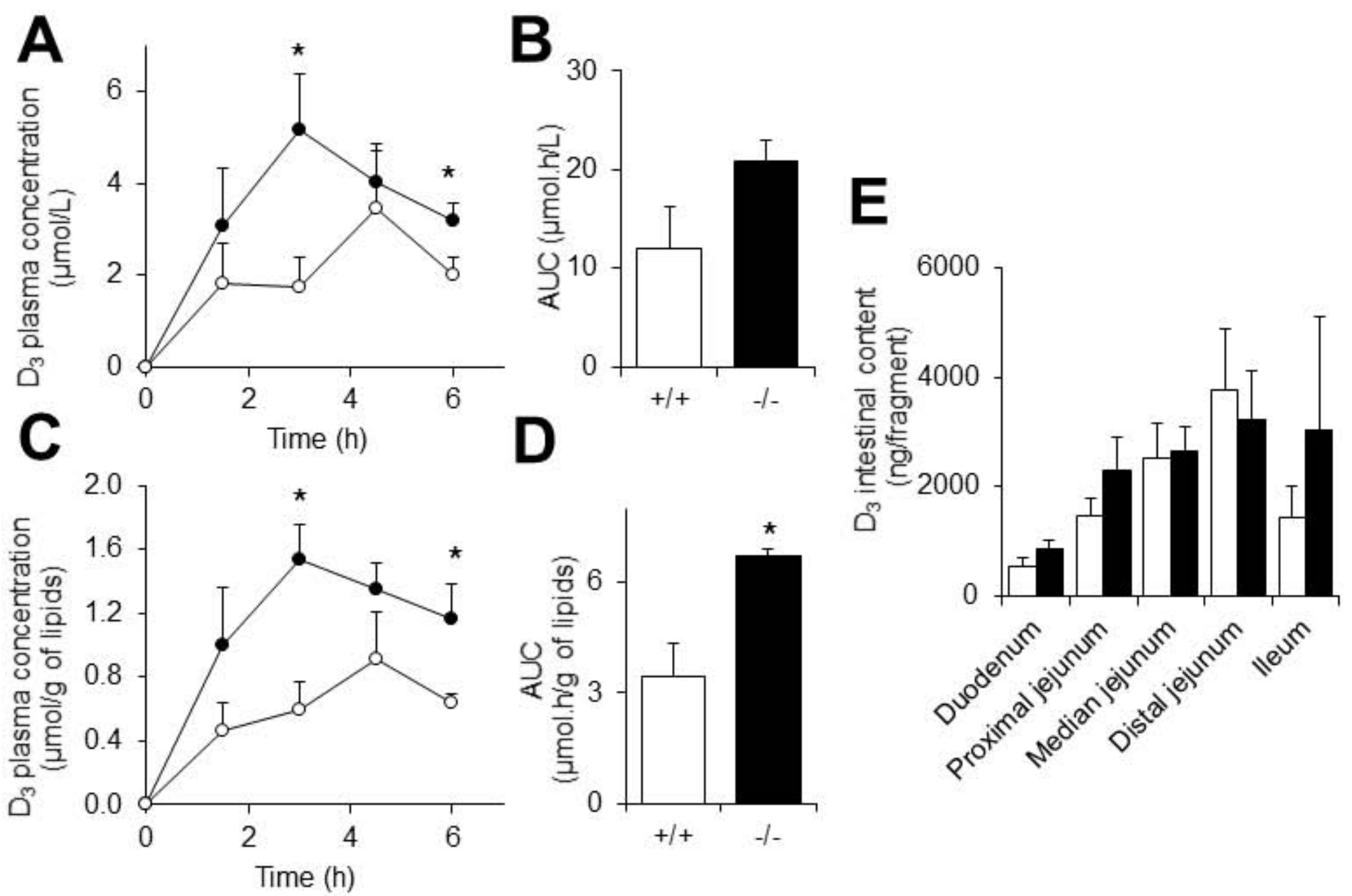

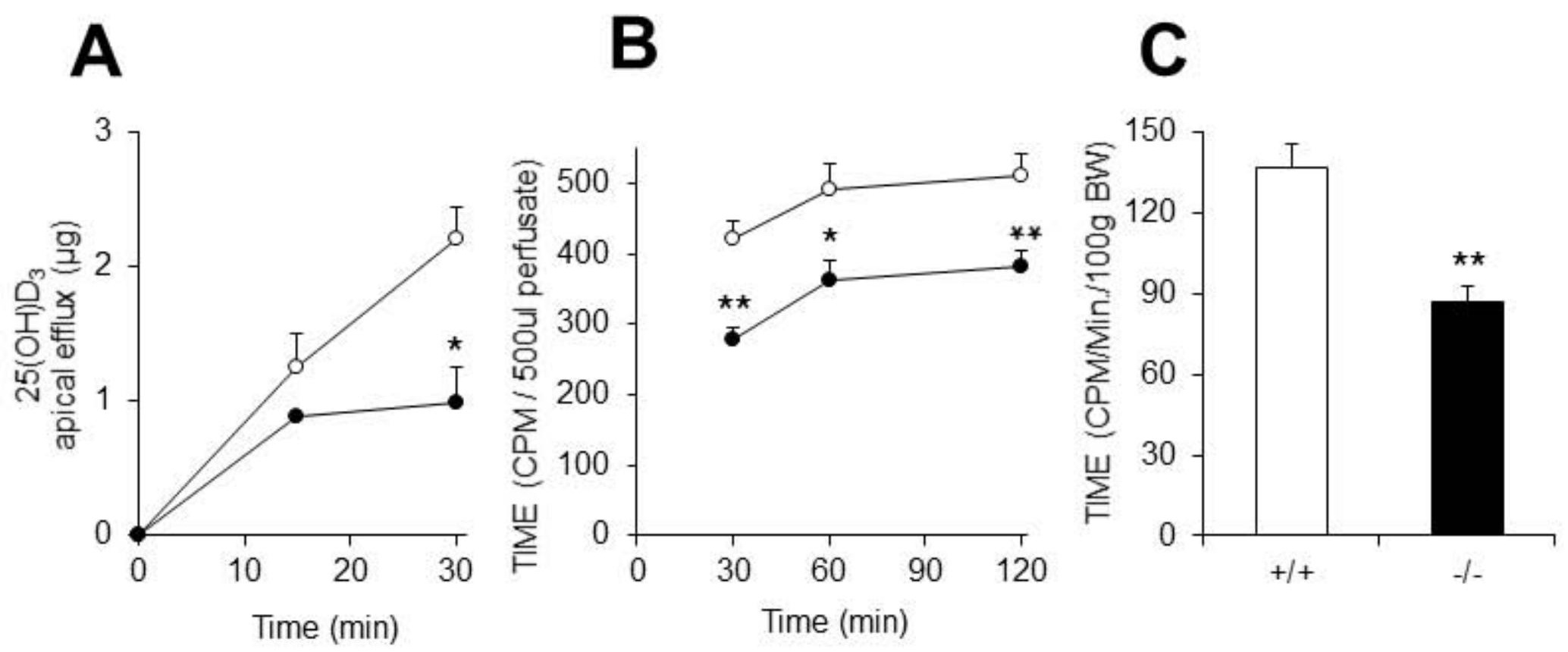
